\title{
SEVERE CARDIAC INSUFFICIENCY SECONDARY TO CARDIOTOXICITY WITH CLINICAL AND MORPHO-FUNCTIONAL IMPROVEMENT AFTER OPTIMISED CLINICAL TREATMENT: CASE REPORT
}

\author{
INSUFICIÊNCIA CARDÍACA GRAVE SECUNDÁRIA A CARDIOTOXICIDADE COM \\ MELHORA CLÍNICA E MORFO-FUNCIONAL APÓS TRATAMENTO CLÍNICO \\ OTIMIZADO: RELATO DE CASO
}

\section{Pedro Ribeiro ROSA ${ }^{1}$; Igor Mychael Melo FERREIRA ${ }^{1}$; Guilherme Silva de MENDONÇA ${ }^{2} *$; Fábio Vieira FERNANDES ${ }^{1}$; Rodrigo Penha de ALMEIDA ${ }^{3}$; Elmiro Santos RESENDE ${ }^{4}$; João Lucas O'CONNELL ${ }^{5}$}

1. Federal University of Uberlândia, Faculty of Medicine, Uberlândia, MG, Brasil; 2. Federal University of Uberlândia, Faculty of Medicine, Uberlândia, MG, Brasil; 3. Federal University of Uberlândia, Faculty of Bioengineering, Uberlândia, MG, Brasil; 4. Federal University of Uberlândia, Faculty of Medicine, Uberlândia, MG, Brasil; 5. Federal University of Uberlândia, Faculty of Medicine, Uberlândia, MG, Brasil. guilherme.silva@ufu.br

\begin{abstract}
Many therapies used for cancer (pathology whose cases are progressively increasing in the world) such as chemotherapy and radiotherapy have numerous adverse effects, with cardiotoxicity being one of the most important. This can be defined from the detection, by an imaging method, of a reduction of at least $10 \%$ in the left ventricular ejection fraction (LVEF), bringing it to a value below $53 \%$. Anthracyclines (such as Doxorubicin), Trastuzumab, and Taxanes (Docetaxel) are among the most associated chemotherapeutics. To emphasize the importance of optimized treatment for heart failure and to review the main updates on the theme of cardiotoxicity. Case report and bibliographic review on the latest updates to the management of cardiotoxicity and associated heart failure. When correctly identifying the main risk factors associated with chemotherapy and the individual to develop myocardial injury, it is possible to perform the monitoring by means of two main predictors: the myocardial tension strength and the biomarkers. In this sense, changes associated with these predictors may allow early intervention through appropriate treatment and, with the advancement of research, even prevention, mainly using the association of Carvedilol with Enalapril. Continuous monitoring and early initiation of drug therapy for heart failure are clearly associated with a lower degree of myocardial injury and a lower rate of complications. In addition, there is still an increasingly promising possibility in relation to preventive drug therapy, however, there is still a lack of studies on this topic.
\end{abstract}

KEYWORDS: Cardiac Insufficiency. Early detection. Chemotherapy. Biomarkers.

\section{INTRODUCTION}

Over recent years, there has been a noted progressive increase in the number of neoplasia cases around the world (SIEGEL; MILLER; JEMAL, 2016). Many therapies used to treat cancer have adverse side effects, with cardiotoxicity being one of their worst side effects. According to the American Society of Echocardiography and the European Association of Cardiovascular Imaging, cardiotoxicity due to chemotherapeutic drugs is defined by the detection, using an imaging method, of a reduction of $10 \%$ (or more) in the left ventricular ejection fraction (LVEF) and reaching below $53 \%$ as a result (PLANA et al., 2014). Chemotherapeutic drugs, such as Anthracyclines (i.e Doxorubicin), Trastuzumab, and Taxanes (Docetaxel), for example, are among those most associated with toxic actions that affect the cardiac muscle (PLANA et al., 2014).

This article aims to briefly describe the reported case of a patient that exhibited an exuberant clinical condition of CI, where the appearance of an important ventricular dysfunction was documented following breast cancer treatment, but presenting good clinical and ventricular function recovery years after classic CI treatment. In addition, it aims to review the main updates on the topic.

\section{MATERIAL AND METHODS}

In this sense, a review of medical records was carried out, as well as the monitoring of the patient's clinical history, to highlight the outcomes of therapy. In addition, a brief review was made, associating the theme to the case described, on 
conduct related to the monitoring, prevention and treatment of cardiotoxicity.

This article was submitted and approved by the Research Ethics Committee, CAAE nr 29825819.1.0000.5152 - Opinion Number: 4.037.581, with the patient in this case authorizing its publication after signing an informed consent form (ICF).

\section{CASE STUDY}

Female patient, currently 61 years old, was diagnosed with malign breast neoplasia (T3N0M0) in 2008 (10 years ago) (AJCC, 2017). She underwent four cycles of chemotherapy with the use of Doxorubicin (in a total accumulated dose of 200 $\mathrm{mg} / \mathrm{m}^{2}$ ), followed by 35 cycles of conventional radiography (in a total accumulated dose of $55 \mathrm{~Gy}$ ) until December 2009 (9 years ago).

Before treatment, the patient was asymptomatic in regard to cardiovascular signs and symptoms, denying the existence of previous cardiovascular events or symptoms. She had performed an electrocardiogram and a thorax radiography, both of which were normal. The Doppler echocardiography assessment, performed before starting treatment, indicated a Left Ventricular End Systolic Volume (LVESV) $=60 \mathrm{ml}$ (normal) and a Left Ventricular Ejection Fraction $(\mathrm{LVEF})=60 \%$. The patient did not perform cardiac follow-up consultation; neither repeated the abovementioned exams during her treatment process.

Three months after finishing the chemotherapeutical and radiological treatments (8 years ago), the patient developed classic signs and symptoms of CI (dyspnoea, orthopnoea, nocturnal paroxysmal dyspnoea, lower limbs swelling, jugular swelling) up to functional class IV in accordance with the classification of the New York Heart Association (NYHA). The patient underwent four sequential hospitalisations aimed at clinical state compensation during a period of 6 months after diagnosis, with hospitalisations at Intensive Therapy
Units being necessary during some of these decompensations. Another echocardiogram was performed (during the first hospitalisation), indicating diffuse and important VE hypokinesis, LVESV $=92 \mathrm{ml}$, and LVEF $=21 \%$, confirming left ventricular dysfunction. Throughout the four hospitalisations (during a 6 month period), there was some initial difficulty in optimising drug therapy for CI. Given the lack of initial clinical response, a referral to the cardiac transplant program was suggested. However, the patient sought a different medical team, which opted for trying once more a progressive optimisation of the drug therapy treatment with the use of classic drugs that act by promoting reverse cardiac remodelling.

For the months and years following, the patient progressed with significant clinical improvement, currently (2018) being at a functional class I (NYHA). During this 8 year period there was also significant improvements in the morph functional parameters, according to an echocardiographic exam performed in 2018: LVESV $=48 \mathrm{ml}$ and LVEF $=71 \%$. In addition, a progressive optimisation of the classic drugs used for CI treatment was achieved. Until recently, the patient was being treated with Carvedilol $25 \mathrm{mg}$ 12/12h, Losartan 50mg 1212/h, Spironolactone $25 \mathrm{mg}$ /day and Ivabradina $5 \mathrm{mg} 12 / 12 \mathrm{~h}$. As there had been significant clinical and echocardiographic improvements, high blood pressure episodes and questioning by the patient on the actual necessity of using all those drugs, the prescription was then modified, and as of today, the patient is being treated with Carvedilol 12,5mg 12/12h and Losartan $25 \mathrm{mg} 12 / 12 \mathrm{~h}$. Baseline heart rate usually sits between 60 and $70 \mathrm{bpm}$ and arterial pressure is kept at adequate levels.

\section{DISCUSSION}

There are two main types of cardiotoxicity described thus far: type I and type II. The following Frame deals with some of their respective characteristics.

Tabela 1. Types of cardiac dysfunction related to chemotherapy (CDRC) and their respective characteristics

\begin{tabular}{|c|c|c|}
\hline & Type I & Type II \\
\hline Distinctive agents & Doxorubicin & Trastuzumab \\
\hline $\begin{array}{l}\text { Clinical measures and } \\
\text { typical response to anti } \\
\text { remodelling therapy (beta- } \\
\text { blockers, ACE Inhibitor) }\end{array}$ & $\begin{array}{l}\text { In most cases, seems to be } \\
\text { permanent or irreversible; The } \\
\text { recurrence after some months or } \\
\text { years can be related to sequential } \\
\text { cardiac stress. }\end{array}$ & 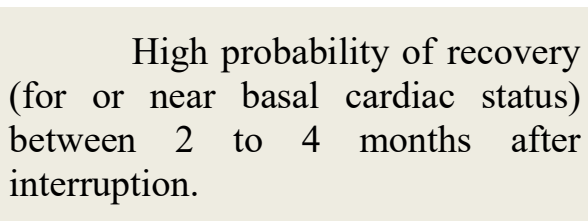 \\
\hline
\end{tabular}


High probability of Re-exposure dysfunction being progressive; can result in cardiac insufficiency or untreatable death.

Vacuoles;

myofibrillar disorder; necrosis (the alterations are generally resolved with time).
Growing evidence for the relative safety of re-exposure (additional data is necessary).

No apparent abnormality (although not having been entirely studied). disorder; necrosis.

Adapted from Ewer and Lippman (2005)

Even though it describes the natural evolution of most patients subjected to the use of mainstream chemotherapeutic drugs, it is known that this classification system also has its exceptions. For example, in some cases in which the drug used is normally associated with Type I cardiotoxicity, even if a dysfunction is detected early on, with chemotherapy being rapidly suspended and ventricular dysfunction treatment started prematurely, a total regression of the dysfunction can still occur within a few months (CARDINALE et al., 2015).

Every time the presence of risk factors associated with the development of cardiotoxicity are detected (more than 65 years of age, positive family history regarding cardiovascular related death, tobacco use, hypertension, diabetes, previous case of coronary or renal disease) aside from the risk factors associated with chemotherapy itself used in treatment (type and dosage of chemotherapeutic drug used) (ARMENIAN et al., 2016), the execution of adequate ventricular function monitoring should also be suggested. Besides these risk factors, the dosage and type of treatment used are also important concerning the possibility of occurring cardiac lesion, as evidenced on the frame below:

\section{Tabela 2. Higher risk of developing cardiotoxicity with a treatment that includes any of the following:}

High doses of anthracyclines (e.g., doxorubicin $>250 \mathrm{mg} / \mathrm{m} 2$, epirubicin $>600 \mathrm{mg} / \mathrm{m} 2$ )

High dose of radiotherapy $(>30 \mathrm{~Gy})$, when the heart is part of the radiotherapy treatment plan.

- Low dosage of anthracyclines (e.g., doxorubicin $250 \mathrm{mg} / \mathrm{m} 2$, epirubicin $600 \mathrm{mg} / \mathrm{m} 2$ ) combined with a low dose of radiography ( $30 \mathrm{~Gy}$ ) when the heart is part of the radiotherapy treatment plan.

- Treatment with a low dosage of anthracycline (e.g, doxorubicin, $250 \mathrm{mg} / \mathrm{m} 2$, epirubicin, $600 \mathrm{mg} / \mathrm{m} 2$ ) or trastuzumab on their own, and the presence of any of the following risk factors: two or more cardiovascular risk factors, including tobacco use, hypertension, diabetes, dyslipidaemia and obesity, during or after completing therapy.

- Treatment with low doses of anthracycline (e.g., doxorubicin, $250 \mathrm{mg} / \mathrm{m} 2$; epirubicin, $600 \mathrm{mg} / \mathrm{m} 2$ ) followed by trastuzumab treatment.

Adapted from Armenian et al. (2016)

Due to its wide availability, safety, low cost and good applicability, trans-thoracic Doppler echocardiogram (ECHO) is the chosen method for cardiac monitoring and assessment (PLANA et al., 2014).

Even though considered the best monitoring parameter, ECHO - 2D presents an incapacity in detecting small LVEF variations (PLANA et al., 2014). As such, two methods have recently come to attention for reaching this goal: the analysis of myocardial tension (calculated by measuring the "myocardial deformations", analysing the SpeckleTracking echocardiography) (CURIGLIANO et al., 2016) and the analysis of myocardial lesion biomarkers. Myocardial tension can be calculated by means of the normal echocardiographic technique, by comparing the global longitudinal strain (GLS) parameter to the echocardiogram. Notwithstanding having a good amount of recent and promising studies on the subject, some controversy persists, being based principally on the presence of variations depending on the quality of the detected image, on the machine used and on the machine operator (CURIGLIANO et al., 2016).

Troponins are among the most used biomarkers. Its predictive value for cardiotoxicity was hinted at studies conducted, which evaluated patients with breast cancer treated with anthracyclines, taxanes and trastuzumab. Patients that had a high concentration of Troponins (> $30 \mathrm{pg} / \mathrm{ml}$ ) were found to have a higher predisposition to develop breast cancer $(\mathrm{p}=0.04)$, with a specificity 
of $73 \%$. However, these are not yet used for defining conduct (SAWAYA et al., 2012).

Drug treatment of cardiotoxicity by use of anthracyclines is based on the usual standard treatment for cardiac insufficiency. Thus, the drug choices at the time our patient started treatment were: inhibitors of angiotensin-converting enzyme II (IACE) or angiotensin II receptors blockers (ARB) in association with beta adrenergic blocking agents (BB). In other words, the treatment for this clinical state must prioritise drugs that work on cardiac remodelling (CARDINALE et al., 2010). Regarding the different drugs in the afore mentioned group, any IACE and ARB can be used. However, among the habitual $\mathrm{BB}$, only carvedilol and nebivolol were tested and approved for this specific clinical state (CARDINALE et al., 2010). In a study conducted by Cardinale e et al (2010), a combined therapy of IACE (Enalapril) and BB (Carvedilol) administered between one month and two after chemotherapy with anthracyclines was administered in patients that exhibited cardiotoxicity with left ventricular dysfunction. In many of the cases (42\%), there was a full recovery of LVEF. In $13 \%$ of the cases, there was partial recovery with an increase of $10 \%$ in LVEF, but still maintained below $50 \%$. Nonetheless, it should be highlighted that for those patients that started treatment late, partial recovery did not take place (CARDINALE et al., 2010).

There has been frequent discussion in recent literature on the possibility of cardiovascular damage prevention in patients subjected to chemotherapeutic treatment. Among the therapeutic options, the drugs used most often for that end are: Dexrazoxane, therapy combined with IACE and BB, aldosterone antagonists, isolated BB, ARB and Statins. Many of these agents have even been associated to benefits such as LVEF preservation and reduced risks of cardiovascular events during therapy (PAYNE; NOHRIA, 2017). The two following studies sought to assess the effects of both combined and independent therapy in the prognostics of patients. In one study conducted by Bosch et al, carvedilol and enalapril were used in an effort to try and prevent myocardial aggression in patients with leukaemia and other haematopoietic malignancies in comparison with a placebo. In total, 90 patients were studied, with 45 receiving combined therapy and another 45 patients constituting the control group. Before treatment, the selected patients did not exhibit left ventricular dysfunction. By the end, those patients that received combined therapy presented a lower death or cardiac insufficiency rate $(6.7 \%$ vs $22 \%)$.

Furthermore, lower rates of mortality, cardiac insufficiency or LVEF below 45\% (6.7\% vs $24.4 \%$ ) were also seen. After six months of monitoring, no major changes in the LVEF of the combined therapy group were detected, while in the control group a LVEF reduction was observed ($3.8 \%$ on average, over the absolute value), with a difference of $3.4 \%(p<0.04)$ between both groups (PAYNE; NOHRIA, 2017). On the other hand, in another study conducted by Gulati et al, the only drugs used were metropolol (BB) on its own, only candesartan (ARB) or metropol combined with candesartan and compared with placebo for preventing cardiac lesion in breast cancer patients being treated with anthracyclines, trastuzumab, taxanes, cyclophosphamides, radiotherapy and/or 5fluorouracil. A total of 120 patients were included in the analysis. The average LVEF of the groups before starting the chemotherapeutic treatment was over $60 \%$. By the end of the monitoring process, a significant correlation between the use of ARB and a reduction in the fall of LVEF was observed. LVEF average reduction was of $2.6 \%$ in the placebo population, while in the ARB-treated population, this reduction was of around $0.8 \%(p=0.026)$. There was no correlation between the use of metoprolol and LVEF reduction ${ }^{10}$. Furthermore, asides from the hitherto exposed, there is currently a noticeable increase in research that associate practice with cardiotoxicity prevention (PAYNE; NOHRIA, 2017).

\section{CONCLUSION}

The identification of patients at higher risk of developing cardiotoxicity, the periodic and routine monitoring of ventricular function after each chemotherapeutical treatment cycle, the use of medicaments that are able to promote the reduction of myocardial damage, the interruption (temporary or definitive) of anti-neoplastic treatment when recommended, and the prompt start to treatment with drugs that can prevent the worsening of cardiac remodelling are fundamental actions for reducing the occurrence of cardiotoxicity related to chemotherapeutical drugs. In addition, promising data is evident, especially in relation to the use of drug therapy as a prevention of cardiotoxicity. However, there is still a need for further studies to corroborate this prerogative. 


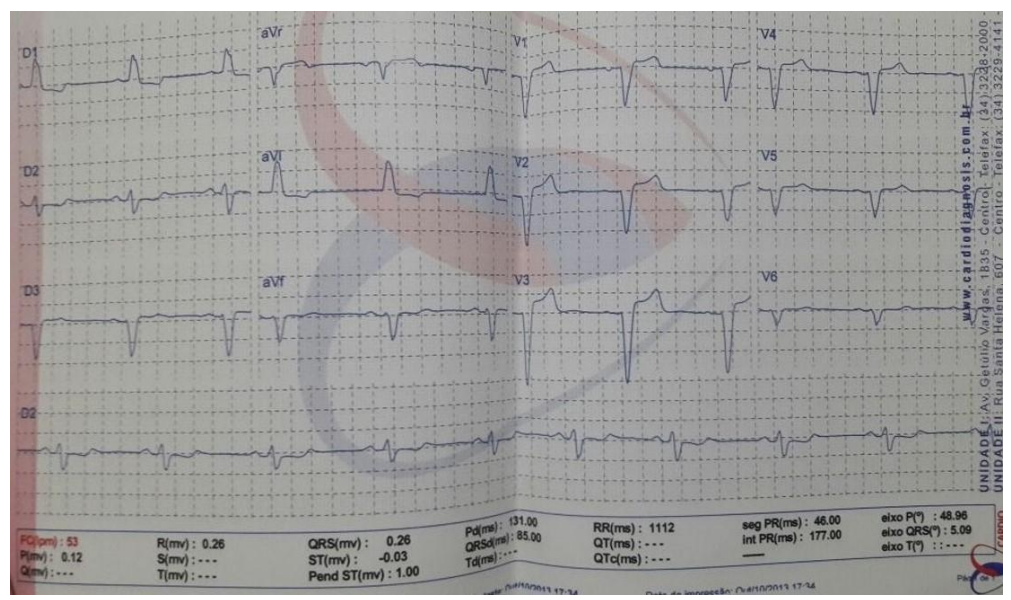

Figure 1. Electrocardiogram (performed in 2013) showing Sinus Rhythm, Left Bundle Branch Block and unspecific Alterations of Ventricular Repolarisation.

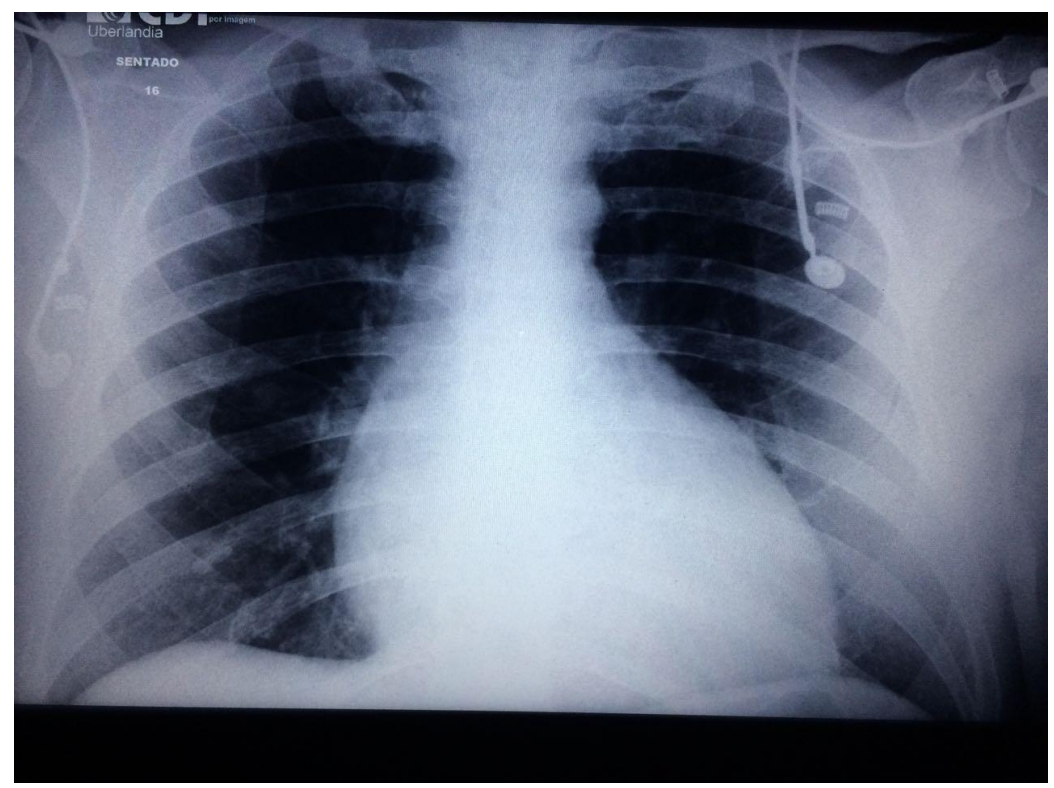

Figure 2. Chest $x$ ray (performed in 2010) showing cardiomegaly and signs of pulmonary edema.

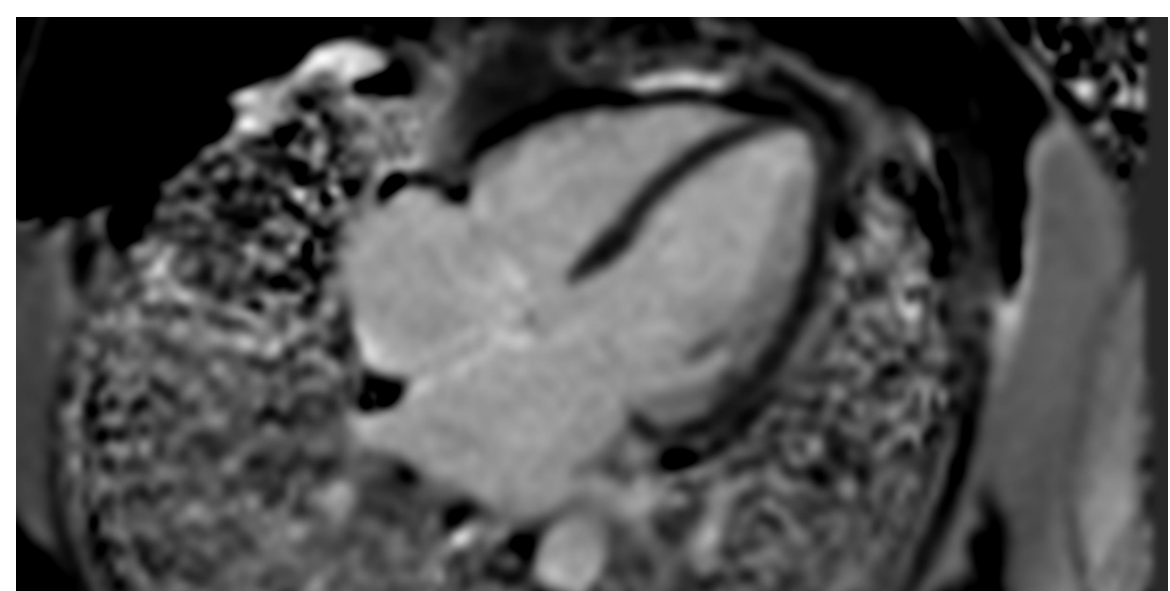

Figure 3. Magnetic resonance during clinical treatment for Cardiac Insufficiency (after partial improvement of clinical condition). 


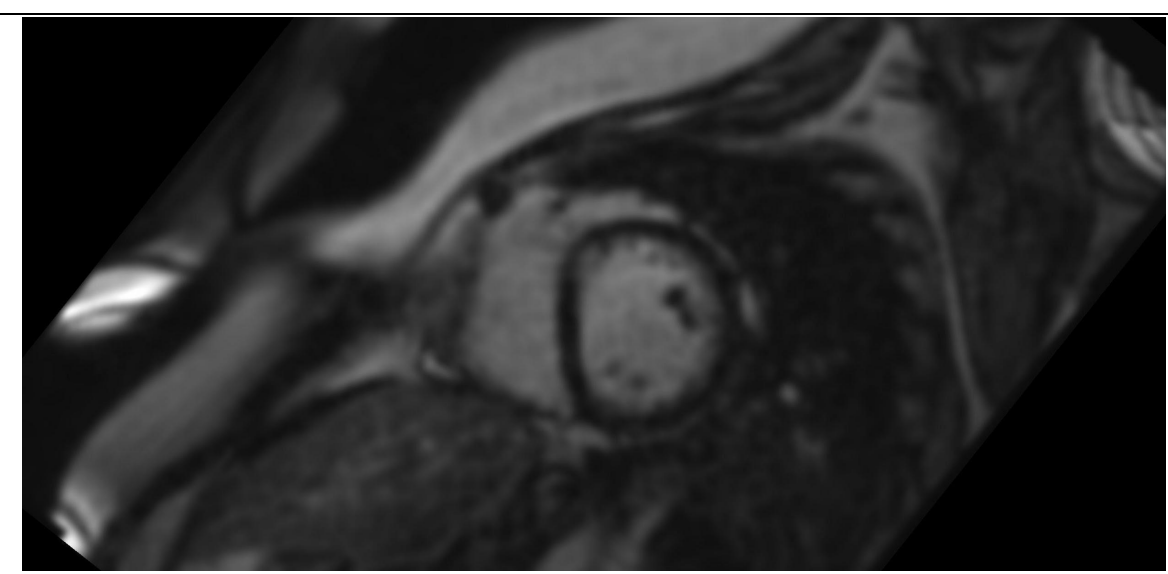

Figure 4. Magnetic resonance during clinical treatment of ventricular dysfunction (after partial recovery of clinical condition).

RESUMO: Muitas terapias utilizadas para o câncer (patologia cujos casos estão aumentando progressivamente no mundo) como a quimioterapia e a radioterapia possuem inúmeros efeitos adversos, sendo a cardiotoxicidade um dos mais importantes. Esta pode ser definida a partir da detecção, por um método de imagem, de uma redução de, pelo menos, $10 \%$ na fração de ejeção do ventrículo esquerdo (FEVE), levando a mesma para um valor inferior a 53\%. As Antraciclinas (como a Doxorrubicina), o Trastuzumab, e os Taxanos (Docetaxel) estão entre os quimioterápicos mais associados. Enfatizar a importância do tratamento otimizado para insuficiência cardíaca e revisar sobre as principais atualizações do tema cardiotoxicidade. Relato de caso e revisão bibliográfica sobre últimas atualizações de condutas referentes ao manejo da cardiotoxicidade e insuficiência cardíaca associada. Ao se identificar corretamente os principais fatores de risco associados à quimioterapia e ao indivíduo para desenvolver a injúria miocárdica, é possível realizar o monitoramento por meio de dois preditores principais: a força de tensão miocárdica e os biomarcadores. Nesse sentido, alterações associadas a esses preditores podem permitir a intervenção precoce por meio do tratamento adequado e, com o avanço das pesquisas, até mesmo a realização da prevenção, principalmente utilizando-se a associação de Carvedilol com Enalapril. Monitorização contínua e início precoce da terapia medicamentosa para insuficiência cardíaca estão claramente associadas com um menor grau de injúria miocárdica e um menor índice de complicações. Além disso, ainda há a possibilidade cada vez mais promissora em relação à terapia medicamentosa preventiva, porém, ainda há carência de estudos em relação a este tema.

PALAVRAS CHAVE: Biomarcadores. Detecção precoce. Insuficiência Cardíaca. Quimioterápicos.

\section{REFERENCES}

AJCC - American Joint Committee on Cancer. Breast. In: AJCC Cancer Staging Manual. 8th ed. New York, NY: Springer, 2017, p. 589.

ARMENIAN, S. H.; LACCHETTI, C.; BARAC, A.; CARVER, J.; CONSTINE, L. S.; DENDULURI, N.; DENT, S.; DOUGLAS, P. S.; DURAND, J. B.; EWER, M.; FABIAN, C.; HUDSON, M.; JESSUP, M.; JONES, L. W.; KY, B.; MAYER, E. L.; MOSLEHI, J.; OEFFINGER, K.; RAY, K.; RUDDY, K.; LENIHAN, D. Prevention and Monitoring of Cardiac Dysfunction in Survivors of Adult Cancers: American Society of Clinical Oncology Clinical Practice Guideline. J Clin Oncol., v. 35, n. 8, p. 893-911, 2016.

https://doi.org/10.1200/JCO.2016.70.5400

CARDINALE, D.; COLOMBO, A.; LAMANTIA, G.; COLOMBO, N.; CIVELLI, M.; DE GIACOMI, G.; RUBINO, M.; VEGLIA, F.; FIORENTINI, C.; CIPOLLA, C. M. Anthracycline-induced cardiomyopathy: clinical relevance and response to pharmacologic therapy. J Am Coll Cardiol., v. 55, n. 3, p. 213-20, 2010. https://doi.org/10.1016/j.jacc.2009.03.095 
CARDINALE, D.; COLOMBO, A.; BACCHIANI, G.; TEDESCHI, I.; MERONI, C. A.; VEGLIA, F.; CIVELLI, M.; LAMANTIA, G.; COLOMBO, N.; CURIGLIANO, G.; FIORENTINI, C.; CIPOLLA, C. M. Early detection of anthracycline cardiotoxicity and improvement with heart failure therapy. Circulation, v. 131, n. 22, p. 1981-8, 2015. https://doi.org/10.1161/CIRCULATIONAHA.114.013777

CURIGLIANO, G.; CARDINALE, D.; DENT, S.; CRISCITIELlO, C.; ASEYEV, O.; LENIHAN, D.; CIPOLLA, C. M. Cardiotoxicity of anticancer treatments: Epidemiology, detection, and management. CA Cancer J Clin., v. 66, n. 4, p. 309-25, 2016. https://doi.org/10.3322/caac.21341

EWER, M. S.; LIPPMAN, S. M. Type II chemotherapy-related cardiac dysfunction: time to recognize a new entity. J Clin Oncol., v. 23, n. 13, p. 2900-2, 2005. https://doi.org/10.1200/JCO.2005.05.827

PAYNE, D. L.; NOHRIA, A. Prevention of Chemotherapy Induced Cardiomyopathy. Curr Heart Fail Rep., Suiça, v. 14, n. 5, p. 398-403, 2017. https://doi.org/10.1007/s11897-017-0353-9

PLANA, J. C.; GALDERISI, M.; BARAC, A.; EWER, M. S.; KY, B.; SCHERRER-CROSBIE, M.; GANAME, J.; SEBAG, I. A.; AGLER, D. A.; BADANO, L. P.; BANCHS, J.; CARDINALE, D.; CARVER, J.; CERQUEIRA, M.; DECARA, J. M.; EDVARDSEN, T.; FLAMM, S. D.; FORCE, T.; GRIFFIN, B. P.; JERUSALEM, G.; LIU, J. E.; MAGALHÃES, A.; MARWICK, T.; SANCHEZ, L. Y.; SICARI, R.; VILLARRAGA, H. R.; LANCELLOTTI, P. Expert Consensus for Multimodality Imaging Evaluation of Adult Patients during and after Cancer Therapy: A Report from the American Society of Echocardiography and the European Association of Cardiovascular Imaging. J Am Soc Echocardiogr., v. 27, n. 9, p. 911-39, 2014. https://doi.org/10.1016/j.echo.2014.07.012

SAWAYA, H.; SEBAG, I. A.; PLANA, J. C.; JANUZZI, J. L.; KY, B.; TAN, T. C.; COHEN, V.; BANCHS, J.; CARVER, J. R.; WIEGERS, S. E.; MARTIN, R. P.; PICARD, M. H.; GERSZTEN, R. E.; HALPERN, E. F.; PASSERI, J.; KUTER, I.; SCHERRER-CROSBIE, M. Assessment of Echocardiography and Biomarkers for the Extended Prediction of Cardiotoxicity in Patients Treated With Anthracyclines, Taxanes, and Trastuzumab. Circulation: Cardiovascular Imaging, v. 5, p. 596-603. 2012. https://doi.org/10.1161/CIRCIMAGING.112.973321

SIEGEL, R. L.; MILLER, K. D.; JEMAL, A. Cancer statistics 2016. C A Cancer J Clin., v. 66, n. 1, p. 7-30, 2016. https://doi.org/10.3322/caac.21332 